\title{
A questão da morte no Ocidente na visão filosófica, histórica e espírita
}

\section{The Question of Death in the West from a Philosophical, Historical philosophical, historical and spiritualist view}

DOI: 10.54018/sssrv3n1-005

\section{Nicolas Theodoridis \\ Formado em História com Pós em História do Brasil, Social, Sociologia e Filosofia. Mestre em História Comparada na UFRJ \\ E-mail: n.theodoridis@uol.com.br}

\section{RESUMO}

A vida realmente nos demonstra a dinâmica em que estamos inseridos. A questão da morte sempre causou profunda introspecção, levando-me, consequentemente, a refletir o modo de como a sociedade ocidental encara o momento, no intuito de compreender a humanidade da morte e a especificidade do humano frente à mesma. Para tal desiderato, foi utilizado três visões diferenciadas sobre o assunto; para a filosofia - Edgar Morin; para a história, Philippe Ariès e na visão espírita, Hermínio de Miranda, Allan Kardec e Francisco Xavier.

Palavras-chave: Morte, Filosofia, História e Espiritismo.

\section{ABSTRACT}

Life really shows us the dynamics in which we are inserted. The issue of death has always caused deep introspection, leading me, consequently, to reflect on the way in which Western society faces the moment, in order to understand the humanity of death and the specificity of the human face to it. For this purpose, three different views on the subject were used; for philosophy - Edgar Morin; for history, Philippe Ariès and in the spiritist view, Hermínio de Miranda, Allan Kardec and Francisco Xavier.

Keywords: Death, Philosophy, History and Spiritism.

\section{INTRODUÇAO}

Herança ancestral trazida de nossas memórias atávicas em que homenageamos aqueles que nos procederam na ida ao túmulo, não existe qualquer grupo, por mais arcaico que fosse, que abandonasse seus mortos ou que os deixasse sem os ritos funerários, sendo, por isso, a sepultura como 0 primeiro dado fundamental e universal sobre a morte humana. Esta morte seria, 
portanto, um prolongamento da vida, apenas sobre outra forma.

Esta mesma consciência negava a morte como aniquilamento e a reconhecia como acontecimento, considerando o funeral como um conjunto de práticas que simultaneamente consagram e determinam a mudança de estado do morto, refletindo na continuidade da presença dele no círculo dos vivos.

Dois tipos de práticas de sepultamentos existiam e coexistem até hoje. A incineração e o sepultamento através do enterro. O domínio da prática da incineração perpassava as antigas civilizações asiáticas e Escandinavas e o sepultamento, no Egito, no Mediterrâneo, China, Europa e América contemporâneas. Embora práticas contraditórias, tinham como princípio basilar evitar o contato com as impurezas do corpo, embora possa ser considerado que a tendência crematista visava à destruição imediata do corpo, onde somente as cinzas eram conservadas, facilitando a transmigração das almas e o sepultamento seria mais propício à ideia da ressureição dos corpos.

Desde o Paleolítico que os mortos nos acompanham, vivendo como os vivos, acompanhados de suas armas e dos alimentos dos quais faziam uso. No mundo ocidental, consta que desde pelo menos o século VIII antes de Cristo, era prática se evocar os ancestrais mortos pedindo que os mesmos protegessem aqueles que ainda permaneciam na terra. $O$ culto aos mortos fez parte da cultura grega e depois da romana estando intimamente ligada ao cotidiano desses povos no passado. Ritos e evocações eram entoados em nome daqueles que já tinham partido. A importância era tamanha que quem dirigia a solenidade era o ancião da família, responsável pela execução perfeita das fórmulas sacramentais.

No Egito Antigo a morte também exercia tremendo fascínio em seus habitantes, tendo esta civilização fantástica criada até o Livro dos Mortos, um verdadeiro compêndio de comportamentos pós-morte.

Poderíamos particularizar cada povo que ascendeu em nosso planeta e explanar sobre como cada um via a morte, mas tal evento traduzir-se-ia em um livro e como não temos essa disponibilidade, vamos nos concentrar na ritualística que estamos imersos em nossa sociedade.

Duas grandes crenças acompanham o homem referente à morte. A primeira diz respeito à morte-renascimento por transmigração e a outra a mortesobrevivência do duplo. O que cada uma destas teorias significa? Bem, o duplo 
significa a sobrevivência individual e as forças de renascimento da morte encontram-se nas religiões de salvação, forças de ressurreição do indivíduo, para que em si próprio, a eternidade o transforme.

Para compreender melhor a questão, a salvação implica na intervenção externa, um deus que arranca os homens da morte e este deus de salvação é aquele cujo poder de ressurreição é utilizado no processo de ressuscitar ele próprio. Independentemente de quem seja este deus, ele é fundamental no drama do próprio mistério da luta contra a morte. Esta salvação é identificada como fé, sendo a recusa da própria fé como recusa da morte e o crente quer ser salvo dela.

O cristianismo é uma religião espiritualista salvacionista, melhor dizendo, acredita em algo mais após o desenlace carnal. O modelo de sobrevivência é essencialmente uma espera e esta se faz em paz e repouso, sendo tal modelo uma das formas mais tenazes das velhas mentalidades, pois está pautado no

pecado original formulado por Agostinho (354 - 430), respondendo pelo sentimento da presença constante do mal. Utilizamos até hoje a réplica quando da morte de alguém - "Que descanse em paz", parafraseando o velho refrão.

A questão da presença da culpabilidade será concentrada no cristianismo e para resgatá-la somente com a morte, pois a morte não é mais do que o castigo do pecado, ou melhor dizendo, do ato sexual adâmico, transformando a salvação de até então, pela redenção da carne, sendo esta o resgate da morte.

Ideia contida em gérmen no Gênesis mosaico, que juntamente com a fábula do pecado original, fez com que o cristianismo fosse uma religião em que o aguilhão da morte fosse o pecado (Paulo), se enraizando na mente dos incautos, expondo a sexualidade e pregando a abstinência e o celibato, pois por mais puro que seja o homem, ele não pode fugir de si mesmo, do qual é fruto.

Observemos o duplo agora. A questão da transmigração tem na reencarnação totêmica o que depois deu origem a metempsicose, ou seja, o renascer em corpo de animal. Nas crenças indígenas e dos autóctones é muito comum à sua visualização. O sacrifício se explicaria através da apropriação da própria imortalidade, pois morte é fecundidade e vice-versa, sendo o sacrifício à exploração mágica, sistemática e universal da força fecundante da morte.

Exemplos não faltam, mas vejamos somente a questão da refeição sacrificial. Inicialmente, comia-se a carne do morto familiar, depois na refeição 
totêmica, o animal do antepassado e por fim, na eucaristia, se consome a carne de Deus mediante a hóstia. Todos têm em comum regenerar a carne dos vivos e assegurar o renascimento.

O duplo tem, em uma das suas manifestações, a presença da sombra. Percebemos isso até na nossa linguagem quando dizemos que tal lugar é assombrado, representando vestígios do tabu em que as sombras seriam sempre perniciosas e tentariam nos prejudicar.

Outra manifestação do duplo seria através do reflexo, que pode ser visual assim como também auditivo (eco). Este aspecto me faz lembrar a questão dos indígenas que ficaram maravilhados com o seu próprio reflexo, lembrando que os gentios tinham como concepção a continuidade do ser em sua comunidade.

O duplo faz parte do conjunto da tradição ocultista, escrita e verbal, vinda de santuários, desde o Egito, Índia, Caldeus até os mais recentes como os Rosa Cruz e Maçons. Todos postulam que o homem é composto por três princípios, o corpo físico, o astral e o espírito imortal. O duplo seria exatamente o astral, identificado por diferentes nomes na literatura mundial em diferentes épocas e que, hoje, com o espiritismo, diríamos que seria o períspirito, a parte do homem que não morre, mantendo, com isso, sua individualidade.

Estes dois conceitos de morte traduzem em si a dialética exigente da individualidade, ou seja, salvar-se da destruição, mas, ao mesmo tempo, penetrar mais intimamente no mundo. $O$ homem, a partir do momento que tem consciência ou sentimento de sua individualidade, vem a odiar a morte, pois ele, como espécie mais desenvolvida, não tem poder sobre ela, nunca podendo penetrar em seus domínios e vir a ressuscitar um Lázaro.

O homem moderno procura fugir da ideia de morte nas suas atividades vinda a esquecer de si mesmo, ignorando que vai morrer em algum momento. Seus ritos, práticas e crenças da morte demonstram ser este ainda o setor mais primitivo de nossa civilização.

Voltando ao cristianismo, com o tempo, tornado religião oficial, se transformou em instrumento do Estado, da sociedade que a governava mediante a classe dominante. Fez com que o indivíduo se transformasse em fiel servidor através do amedrontamento, maculado pela máscara do divino, que Ihe havia prometido a imortalidade e agora o ameaçava com a condenação eterna. Esta 
mesma religião que o adormeceu com medo da morte, mas o manteve acordado com o desejo de imortalidade, com fins de subserviência a este mesmo estado.

Desde o século primeiro, os cristãos rezavam pelos falecidos. Costumavam visitar os túmulos dos mártires nas catacumbas para rezar pelos que morreram sem martírio. No quarto século, já encontramos a memória dos mortos na celebração da missa. No século seguinte, a Igreja dedicaria um dia por ano para rezar por todos os mortos, pelos quais ninguém rezava e dos quais ninguém já se lembrava. Conforme os lugares, as comemorações ao dia dos mortos ocorriam em datas diferentes, como por exemplo, 26 de janeiro, 17 de dezembro (Santo Inácio) e na segunda feira de Pentecostes.

O Abade da Ordem de Cluny, Santo Odilon, em 998, pedia aos monges que orassem pelos mortos. No século XI, os papas Silvestre II, João XVII e Leão IX obrigam a comunidade a dedicar um dia específico aos mortos. Com isso, no século XIII, o dia escolhido para comemorar fica estabelecido em 02 de novembro, visto que, no dia 01, ser a Festa de Todos os Santos e se propagou por toda a cristandade latina.

O Dia de Todos os Santos celebra todos os que morreram em estado de graça, mas que não foram canonizados, e o dia 02, os que morreram não estando em estado de graça total, mais precisamente os que se encontram em estado de purificação de suas faltas e assim necessitam de nossas orações.

Com o advento do Protestantismo no século XVI, os mesmos afirmaram que a oração aos falecidos é desprovida de fundamento bíblico. Segundo a interpretação protestante, a Bíblia diz que a salvação de uma pessoa depende única e exclusivamente da sua fé na graça salvadora que há em Cristo Jesus e que esta fé seja declarada durante sua vida na Terra e que após sua morte, a pessoa passa diretamente pelo juízo e que vivos e mortos não podem se comunicar de maneira alguma.

Os protestantes observam o dia de Finados para lembrar-se das coisas boas que os antepassados deixaram como o legado de um caráter, por exemplo, mas acreditam que as pessoas precisam ser cuidadas, unicamente, enquanto estão vivas.

Um dado curioso a respeito do Feriado de Finados é que, embora originado do Cristianismo, foi nomeado de forma diversa à real celebração cristã. $\mathrm{Na}$ 
realidade, o cristianismo, ao contrário do feriado brasileiro, celebra a lembrança dos fiéis defuntos e não o dia de finados. Qual a diferença afinal?? No aspecto etimológico, verificamos que a palavra finado significa em sua origem aquele que se finou, ou seja, que teve seu fim, que se acabou, que foi extinto. A palavra defunto, por sua vez, originada do latim, era o particípio passado do verbo "defungor", que significava satisfazer completamente, desempenhar a contento, cumprir inteiramente uma missão. Mais tarde, foi utilizada e difundida pelo cristianismo para dizer que uma pessoa morta era aquela que já havia cumprido toda a sua missão de viver. Modernamente virou sinônimo de cadáver.

Com isso, o dia dos Fiéis Defuntos é, portanto, o dia em que a Igreja celebra o cumprimento da missão das pessoas queridas que já faleceram, através da elevação de preces a Deus por seu descanso junto a Ele.

O dia 02 de novembro é, portanto, o dia elegido para lembrar-se dos mortos, certo? Bem, vejamos por outro ângulo. Sem entrar em divagações sobre o significado da morte que nos levaria a outra vertente, vamos atentar ao costume de irmos ao cemitério com fins de prestar reverência aos nossos entes falecidos ou então àqueles que nos são caros por qualquer motivo.

Como o intuito é de cultivar a memória daqueles que já partiram, podemos e devemos efetuá-los com a elevação de nossos sentimentos. É bom sentirmos saudades. Significa que há amor em nossos corações, o sentimento supremo que empresta significado e objetivo à vida. O fato de instituir um dia específico para tal ato não significa que devamos consagrar somente esse dia determinado e sim que cultivemos a lembrança saudável do ente ausente corporalmente.

A morte nos arrebata pessoas queridas e vemos como em muitos o fardo de tal perda se torna quase que insuperável. Não permitamos que a saudade se converta em motivo de angústia e apreensão. Usemos os filtros da confiança e da fé, dulcificando-a com a compreensão de que as ligações afetivas não se interrompem com a sepultura. O amor, essência da Vida, estende-se indestrutível as moradas do Infinito, ponte sublime que sustenta indelevelmente a comunhão entre Terra e Céu.

A convencionalidade da sociedade que estabelece um padrão comportamental com a ida aos cemitérios é puramente social. Aqueles que fazem parte de nossas vidas sempre nos acompanharão mergulhados em nossas 
memórias. Caso formos capazes de orar, contritos e serenos nesses momentos de evocação, orvalhando as flores da saudade com a benção da esperança, sentiremos a presença deles entre nós, envolvendo suavemente nossos corações com cariciosos perfumes de alegria e paz.

Voltando aos tempos atuais, um dos questionamentos era referente ao espaço em que agora me encontrava, ou seja, o hospital. O século XX representou uma mudança significativa do espaço da morte. Antes, era uma morte pública, localizada no ambiente familiar, cercada pelos familiares e amigos, mas com os progressos obtidos no campo da higiene, das ideias de assepsia e do maquinário pesado necessário para a internação do profitente, o local da morte se transferiu para o hospital.

Entendamos. Mediante o progresso, principalmente pós-segunda guerra mundial (1945), as técnicas cirúrgicas e médicas necessitavam de material complexo além de pessoal qualificado. Estas condições somente eram reunidas no espaço hospitalar, fazendo com que o espaço físico não fosse somente o local do saber médico, mediante observação e ensino, mas também de concentração de serviços considerados auxiliares, tais como laboratórios e de aparelhos específicos para diagnóstico de determinadas sematologias.

Além disso, outra mudança na mentalidade das pessoas se refere ao aspecto do mal. A doença era suja e as pessoas não conseguiam mais conviver com isso. Na ldade Média, o cemitério era local de encontro das pessoas, pois não existiam outros locais possíveis de aglomeração. O convívio quase que diário da presença da morte fazia com que os odores exalados fizessem parte do cotidiano destas pessoas. Todos conviviam com condições consideradas hoje extremamente insalubres, motivo tal de tantas epidemias das quais as populações eram acometidas.

O que antes não causava náuseas acabou virando um espetáculo repugnante e mais ainda, inconveniente, com os chamados atos biológicos do ser humano. As secreções do corpo não podiam mais ser públicas, exceto a alguns íntimos, que pudessem acompanhar no quarto o cheiro proveniente da urina, suor, fezes, gangrena, etc. A morte fica escondida em um quarto de hospital, pois o antigo quarto domiciliar se transferiu para lá, com a anuência da família, visando uma adequação mórbida e também pela vida frenética que levamos hoje, sem que 
haja tempo hábil para se dedicar a um moribundo.

O hospital ainda tem outra característica. A questão de atenuação ou supressão do sofrimento e da sensibilidade. Em casa, tal procedimento não teria como ser efetuado, mas com as atuais técnicas medicinais isso é possível. O hospital faz parte de uma burocracia em que a estrutura de seu poder reside em disciplina, organização e anonimato, constituindo um novo modelo de morte medicalizada, ou seja, um style of dying.

O recurso ao médico se tornou condição sine qua non nesta nova sociedade de faceta industrializada e urbana, vindo a substituir o papel do padre nas últimas horas. A extrema unção foi substituída, deixando de ser o sacramento dos moribundos para ser o dos mortos. Essa característica é compreendida, pois, criou-se uma postura pautada na mentira, em que a verdadeira situação em que o doente se encontrava, era escondido, com o temor de magoá-lo e o levar ao desespero. Os familiares dissimulavam a condição da gravidade em que o doente se encontrava e, este por sua vez, também aceitava o jogo, cada qual cúmplice do outro.

Tem um pudor que faz com que as crianças sejam afastadas do ambiente da morte, dissimulando o ocorrido com o parente (geralmente pai e/ou mãe), cessando o enterro como espetáculo familiar. A morte começou a ser tratada em segredo e de forma velada.

Uma das imagéticas mais assustadoras hodiernamente é a morte no hospital em que o profitente está eriçado de tubos, sabedor do fim eminente. 0 ambiente é silencioso, não se pode fazer barulho, frio, devido à conservação necessária do maquinário e distante do aconchego do lar, cercado por profissionais da saúde que se revezam no intuito de amenizar o sofrimento.

A bela morte é a morte na casa, cercado pelos recônditos íntimos e familiares de nossa moradia. Tanto no catre da enfermaria, como da clínica luxuosa, as vozes se elevam em coro uníssono provenientes dos gritos dos moribundos em uma súplica para que os levem para as suas casas para que arfem os últimos suspiros lá.

O declínio do luto também foi outro fenômeno observado sendo este substituído pelo culto da lembrança no lar. A dor da saudade continua, mas as manifestações não mais podem ser exaradas em público, regra esta adotada em 
todo o Ocidente. Quem já não teve um parente próximo ceifado pela morte e ficou de "luto" com os dias concedidos pelo empregador. Este é o modelo atual, depois disso, vida que segue, pois a crise de choro ou de nervos demonstra fraqueza de caráter.

O luto exprime socialmente a inadaptação do indivíduo à morte sendo, ao mesmo tempo, o processo social de adaptação que é responsável pela cicatrização das feridas abertas nos indivíduos que sobrevivem.

O convívio com a presença da morte era rotina antes dos progressos conseguidos pela longevidade, pois fazia parte dos riscos diários. O luto do período medievo era mais social do que individual, isso porque a pessoa se via como grupo, pertencia à cristandade e sua presença fazia parte do cotidiano do seu ambiente. Com a mecanização e a urbanização, tais posturas ficaram relegadas ao privado e a morte sem sentido do coletivo.

A morte já não pertence ao indivíduo e nem à família, mas está regulada e organizada por esta burocracia da qual faz parte, mesmo que na maioria das vezes inconsciente de sua condição, traduz um contexto de sua época. Este dispositivo psicológico retirava a morte da sociedade e a deixava reservada, principalmente aos próximos.

A morte virou uma indústria e das mais movimentadas. Hoje se disputa os mortos, os famosos, lógico. Tenho conhecimento de artistas que ao exalarem o último suspiro, tiveram seus cadáveres negociados pelos familiares com vários cemitérios, pois a presença de determinada personalidade é capaz de atrair multidões e multidões significam consumo e consumo é sinônimo de lucro.

Vejamos o exemplo do caixão. Usado inicialmente somente como transporte dos corpos inertes para a vala comum, onde eram jogados, foi aos poucos se modificando e se tornando objeto de barganha. Os primeiros empresários, ou mais conhecidos como agentes funerários, que a priori alugavam carruagens para fins de remoção e transporte do caixão, explorando o mercado da morte como qualquer outro mercado econômico, sem maiores considerações pela dor. Hoje, é possível verificar que pelo menos um de nossos parentes mais velhos possuam túmulos reservados e/ou planos assistenciais que se encarregam dos pormenores do enterro.

Tratamos não mais dos indivíduos, mas das doenças que os acometem. 
Afinal de contas, o que são as doenças? Como podemos compreendê-las? Vejamos:

Todos nós nascemos e vivemos imersos em um mundo que não nós é visível. As bactérias, vírus, fungos e outros tantos seres nos acompanham a vida toda. Temos em nosso corpo uma imensa colônia de bactérias que são extremamente necessárias para um bom funcionamento da máquina corporal. Exemplo disso é a chamada flora bacteriana que todos temos para efetuar o processo digestivo do qual sem ela não seria impossível viver.

$\mathrm{Na}$ condição chamada de saúde, estamos sempre com o corpo em harmonia, ou seja, os elementos que teoricamente seriam benéficos, agindo de maneira desordenada, acabam criando o desajuste corporal, incutindo no que identificamos como doença.

O mais interessante é que muitos dos elementos exógenos, quando estamos com baixa imunidade, produzem diversos processos de resposta no corpo somático. Pelo entendimento do Espiritismo, tem-se a prerrogativa de que, como vivemos em um mundo de Provas e Expiações, estaríamos retirando as mazelas perispirituais, drenando-as no corpo físico. Prova disso é que existe uma série de doenças consideradas raras e sem nenhum tipo de tratamento e até de entendimento de como acontecem, pois, determinadas manifestações no físico não são para terem cura, digo, o corpo, como último estágio da matéria mais grosseira, estaria expurgando os males do espírito, efetuando a devida limpeza do perispírito.

Até chegar a este raciocínio, as pessoas passam por diferentes graus de revolta, indignação e possivelmente de resignação referentes ao que estão sofrendo. Mais do que compreensível, mas também o devido entendimento de que a doença que lhes acomete é fruto de um beneplácito divino que está permitindo que ele, como espírito, tenha a possibilidade de drenar seus corpos espirituais, no mínimo é reconfortante.

Outra possível reflexão parte da premissa de que tal processo faz parte de algo maior, ou seja, o corpo nada mais é do que o veículo de manifestação do espírito naquela determinada encarnação e que, o que lhe acomete é passageiro e fruto somente de um período de um lapso no tempo.

Somos prisioneiros de nossas próprias células, pois fomos nós que as 
viciamos. A causa é de ordem mental, espiritual e física, pois como somos nós mesmos os responsáveis, os programamos conforme nossas atitudes, pois o desenlace carnal apenas nos retira o fardo de um corpo, mas os outros nos acompanham na Erraticidade e na volta, assim como todas nossas idiossincrasias.

Ao reencarnar, o espírito se vê preso inicialmente ao encarceramento da carne e depois às células perispirituais do corpo das quais ele próprio corrompeu. A genética espiritual terá imensa dificuldade em descondicionar àquilo que por hábito tenha sido alvo de ações atávicas.

Utilizando a prédica cristã, de que colhemos o que plantamos, as doenças das quais estamos sujeitos, seriam instrumentos divinos para resgate dos erros pretéritos e, para tal, o corpo físico utilizado como captação destas doenças. $O$ corpo físico é também campo de colheita e plantio. A doença no corpo é simplesmente o extravasamento de um mal que vem se acumulando nas células e nos órgãos.

As doenças, quaisquer que sejam, não possuem remédios. Criam-se ilusões de cura, quando na verdade fomos apenas sugestionados para que, por nós mesmos, tivéssemos capacidade de mobilizar a chamada auto cura. Este ponto é crucial. Somente nós é que podemos ser os artífices de nossa felicidade e não o outro. Acaso estivesse eu resfriado, adiantaria alguém tomar um remédio por mim?? Faria diferença ou me melhoraria? Claro que não, portanto, eu sou o meu maior responsável.

Esse é inclusive um dos meus argumentos quando ouço alguém dizer que "encontrou Jesus", mas a intermediária foi determinada Igreja. Bem, a fé simbolizada em Jesus foi que movimentou as forças divinas existentes em nós, forças essas que se sobrepõem àquelas que nós mesmos desencadeamos ao corromper e degenerar nossos organismos físicos e perispirituais e ele, somente ele, foi o responsável pela mudança, sem necessitar de intermediários para isso. Infelizmente ainda não chegamos ao ponto de fazermos tudo sozinho.

Com isso, qualquer enfermidade quando se exterioriza, está na realidade chegando à sua fase terminal. A pior doença caracteriza-se por se esconder nos refolhos da personalidade e nas entranhas das células, pois, até que se manifeste, o espírito ainda estará preso dentro das amarras do débito que caracterizam o 
retorno ao corpo até que tenha pago o último ceitil ${ }^{1}$. O espírito, livre da expiação, tem uma caminhada a seguir, já isento daquela prova. Em futura encarnação, o postulante virá a ter sua matéria bruta melhor formada, isenta dos males pretéritos, isto é, conforme também asseverou Jesus, caso não volte a cometer os mesmos desatinos, "vá e não peques", pois se isto acontecer, seu corpo viria a sofrer com seus desajustes morais. Jesus com suas palavras tácitas nos advertia mediante os débitos adquiridos perante e Lei Divina que jaz grafada na consciência, afirmando que não haveremos de nos isentar de nossas culpas enquanto não as houvermos sanado completamente.

A proximidade da morte faz com que reflitamos sobre as possibilidades do que encontraremos pela frente. Será o fim de tudo? Um nada, conforme insistem os materialistas? Que nada mais somos do que a reunião de átomos e que com o processo de entropia, findamos nossa existência? Parece-me muito simplório tal visão. Teríamos sido criados, ou conforme afirmam os representantes desta corrente, fruto de simples coincidência e aglomeração molecular fortuita, para então, depois de uma existência, sermos riscados simplesmente do mapa?

Se o século XX representou uma ruptura no espaço da morte, desde a segunda metade do século XIX já se evidenciava uma crise na chamada morte. O niilismo representado por Friedrich Nietzsche (1844 - 1900) formou o caldo das angústias, vendo a morte como um nada, numa única decomposição, a morte, o fim. Esta angústia continuou a se acentuar, vindo a se tornar denominador comum nas filosofias de Soren Kierkegaard (1813 - 1855), Martin Heidegger (1889 1976) e Jean Paul Sartre (1905 - 1980). A angústia é a própria morte, morte esta que representa o fim, solitária e única. Por que isso?

$\mathrm{Na}$ ciência moderna, o pensamento cartesiano (René Descartes) separou a mente da matéria. Este modelo mecanicista, sustentado posteriormente por Sir Isaac Newton, acabou se tornando o alicerce da física clássica ocidental, diferente da oriental, onde a mesma enfatiza a necessidade de uma visão holística do homem, ou seja, a consciência da unidade do todo e de sua interação para com todas as coisas.

Isaac Newton (1643 - 1727) foi o fundador da Física moderna. Segundo ele, todos os fenômenos celestes, em qualquer de suas expressões, podiam ser

1 - Menor parte da moeda romana de cobre, o denário. 
estudados conforme rígidos e lógicos princípios pré-estabelecidos. Com isso, o universo converteu-se em uma gigantesca máquina e Deus era o seu mecânico, garantindo a estabilidade e o perfeito movimento de suas peças.

René Descartes (1596 - 1650) foi o mais profícuo iluminista francês e para ele o Universo era preenchido por vórtices fluídicos que faziam rodopiar os astros como rolhas em redemoinhos d'água. O Universo cheio de fluidos de Descartes terminou por se unir facilmente ao de Newton compondo uma unidade estática, eterna no tempo e infinita no espaço.

A visão deísta, tendo como pilares Newton e Descartes, sustentava que Deus criara o Universo, porém se apartara dele, uma vez que este se auto organizaria e se manteria por meio de suas próprias e precisas leis.

Fritjof Capra coloca que a cultura ocidental é além de mecanicista e fragmentária, extremamente valorizada pelo saber da ciência academicista e coloca em plano inferior o conhecimento intuito e filosófico.

A visão holística do universo começa a ser desvelado mediante as revelações da Física Quântica, à medida que os diversos modelos subatômicos da matéria vão sendo percebidos como interligados em mútua interação e interdependência entre eles.

Stephen Hawking (1942 - 2018) nega a criação e se calca no fato da imperfeição da matéria e no processo de entropia (desagregação molecular), responsável pela decomposição da matéria orgânica. Aceitar o nada é muito mais cômodo do que tentar explicar algo que permeia as mentes mais brilhantes em todos os tempos.

Entendendo as premissas que levaram Hawking a negar Deus, iremos explorar a lógica aristotélica para explicar Deus. Sendo Deus a causa primária de todas as coisas, a origem de tudo o que existe, a base sobre o qual repousa o edifício da criação, é também o ponto que importa considerarmos antes de tudo.

Constitui princípio elementar que é pelos seus efeitos que se julga uma causa, mesmo quando ela se conserve oculta. Ora, se existe um efeito é porque existe uma causa, e se existe um efeito inteligente é porque existe uma causa inteligente. Em toda parte, se reconhece a presença do homem pelas suas ações. Pois bem, lançando o olhar sobre as obras da Natureza, notamos a Providência, a sabedoria, a harmonia que presidem a essas obras, reconhece o observador 
não haver nenhuma que não ultrapasse os limites da mais portentosa inteligência humana. Ora, se o homem não as pode produzir, é que elas são produto de uma inteligência superior à Humanidade, a menos que se sustente que há efeitos sem causa.

Poderemos com tais observações encetar algumas dúvidas. As obras ditas da natureza são produzidas por forças materiais que atuam mecanicamente, em virtude das leis de atração e retração; as moléculas dos corpos inertes se agregam e desagregam sob o império dessas leis. As plantas nascem, brotam, crescem e se multiplicam sempre da mesma maneira, cada uma na sua espécie, por efeito daquelas mesmas leis; cada indivíduo se assemelha ao de quem proveio; o crescimento, a floração, a frutificação, a coloração se acham subordinados a leis materiais, tais como o calor, a eletricidade, a luz, a umidade, etc.. Portanto, segundo esse raciocínio, as forças orgânicas da Natureza são puramente automáticas, correto?

Tudo isso é verdade; mas, essas forças são efeitos que hão de ter uma causa e ninguém pretende que elas constituam a Divindade. Elas são materiais e mecânicas; não são de si mesmas inteligentes, também isto é verdade; mas, são postas em ação, distribuídas, apropriadas às necessidades de cada coisa por uma inteligência que não é a dos homens. A aplicação útil dessas forças é um efeito inteligente, que denota uma causa inteligente.

O que podemos constatar é que Deus não se mostra, mas se revela pelas suas obras. A existência de Deus é, pois, uma realidade comprovada não só pela revelação, como pela evidência material dos fatos.

A negação de Hawking parte daquilo que ele crê, de que a matéria sendo corruptível e deteriorável, não é possível que venha a fazer parte da natureza de Deus. Entendo seu ponto de vista, tendo como elemento a matéria, mas vale fazer uma ressalva. Se nos atentarmos somente ao aspecto material, essa avaliação está corretíssima, mas se agregarmos algo mais, ou seja, o princípio espiritual, veremos que a matéria na realidade serve de suporte para a evolução do espírito.

Entendamos a entropia. A matéria em suas múltiplas manifestações orgânica tem "prazo de validade". Olhemos nossos corpos. O processo ontogênico (crescimento desde a fecundação do ovo até a fase adulta) repete a filogenia (desenvolvimento específico de cada espécie). Por melhor que cuidemos 
do corpo, ele sofre desgaste com o tempo, mas não ocorre a desagregação das moléculas do corpo. Esse processo somente terá início quando do fenômeno chamado morte. Nesse instante, o que mantinha unidas as moléculas se desfaz e se tem início a entropia da matéria. Pergunto a todos. Qual é o elemento que possibilita a união molecular??? A resposta é simples e já conhecida desde a Antiguidade, o Espírito.

Ao colocar o vazio da criação em cima do nada, Hawking nega o aspecto mais fenomenal do homem como parte da criação e torna a criação e nós mesmos como meros fantoches representando na vida, pois de que serve tudo isso, afinal? Se viemos do nada, para o nada voltaremos, certo?

A ciência, orgulhosamente, retirando Deus de seu caminho, assume o controle da criação, enxergando-a como um imenso maquinário submetido à independência das leis físicas. O pensamento humano bifurcou-se, o corpo físico, apartado do espírito, torna-se apenas matéria.

Pegando o gancho a respeito da matéria, novamente segundo o espiritismo, nas questões 25 e 27 do Livro dos Espíritos, a mesma postula que existem dois elementos gerais no Universo que são; o espírito e a matéria, mas para que a matéria possa ter inteligência, é necessária à sua união com o espírito.

Sua importância se faz sentir cada vez mais na penetração de seus princípios filosóficos nos dias atuais e demonstra sua precocidade ao tratar de assuntos que somente agora estão se descortinando.

Quando tivermos compreendido e conjugado as forças que nos regem, iremos com certeza olhar para trás e ver como éramos atrasados e, ao encararmos a frente, teremos a certeza de que somos fruto do amor de Deus, criaturas geradas em seu seio Divino, com a finalidade de crescermos e aprimorarmos nossas qualidades inatas, somente esperando o campo fértil para o plantio.

André Luiz, no cap.3 do livro No Mundo Maior (1994, p. 45) coloca que

A crisálida da consciência, que reside no cristal a rolar na corrente do rio, aí se acha em processo liberatório; as árvores que por vezes se aprumam centenas de anos, a suportar os golpes do Inverno e acalentadas pelas carícias da Primavera, estão conquistando a memória; a fêmea do tigre, lambendo os filhinhos recém-natos, aprende rudimentos do amor; o símio, 
guinchando, organiza a faculdade da palavra. Desde a ameba, na água tépida do mar, até o homem, vimos lutando, aprendendo e selecionando, invariavelmente.

Portanto, segundo o espiritismo, somos seres egressos da matéria primordial, o átomo vivificado pela presença do princípio inteligente, que no transcurso evolutivo chegou ao patamar de espírito/homem, consciente e que continua até o anjo, identificado como o mais alto grau de perfeição da criação.

A palavra átomo é derivada do grego. Seria, segundo eles, a menor parte da matéria. O prefixo "a" significa ausência e "tomo" divisão, portanto, sem divisão. Daí, que vemos coleções de livros um pouco mais antigas que têm em suas divisões tomo 1 , tomo 2 e por aí vai.

O ser humano tem aproximadamente 7.000.000.000.000.000.000.000.000.000 (são 27 zeros à direita) de átomos. $\mathrm{A}$ gigantesca sequência é pronunciada como sete octilhões e corresponde à quantidade de átomos que formam o corpo humano. Essa é apenas uma das incríveis curiosidades a respeito do que compõe a nossa matéria. O corpo humano possui 10 trilhões de células, mas as bactérias estão presentes em número muito maior. Embora não sejam precisas, estimativas indicam a existência de ao menos 10 microrganismos (entre bactérias, fungos, amebas, vermes e parasitas) para cada célula.

Estas bactérias são fundamentais para o equilíbrio do corpo. "Por exemplo, no caso dos microrganismos que são encontrados na flora intestinal, podemos dizer que eles auxiliam no processo de metabolismo dos nutrientes, produzindo inclusive algumas vitaminas essenciais, facilitando a absorção e eliminando produtos que poderiam ser tóxicos, mas seu crescimento exagerado pode resultar em problemas de saúde", esclarece o doutor em Ciências Biológicas Pietro Ciancaglini, professor titular do Departamento de Química da Faculdade de Filosofia, Ciências e Letras de Ribeirão Preto da Universidade de São Paulo (FFCLRP-USP).

Os átomos que compõem a matéria jamais se tocam. São sete octilhões de átomos separados entre si. As ligações químicas (ligações covalentes, metálicas, iônicas, etc.) possibilitam os diferentes compostos. É o que forma a matéria. Tais ligações são compartilhamentos de elétrons entre os diferentes átomos, os quais 
passam a fazer parte não apenas da nuvem eletrônica de um único átomo, mas dos dois átomos que agora estão unidos. Cada molécula é a base da formação dos diferentes compostos, que, por sua vez, compõem as diferentes células que constituem o corpo humano.

Outro detalhe interessante é que os átomos são compostos de grandes espaços "vazios". Noventa e nove por cento, segundo a física quântica. A sua estrutura é similar à do sistema solar: uma parte central concentra a massa (núcleo/sol) e partículas giram ao seu redor (elétrons/planetas). Os elétrons, porém, se movimentam como ondas. Sua trajetória não é determinada por uma órbita regular, mas por um cálculo de probabilidades. Como já diziam os antigos, "assim como é no macro, é no micro", não dizemos na Oração do Pai Nosso "Assim na Terra como no Céu"...

O corpo humano é constituído por trilhões de células, compostas por octilhões de átomos, que se estruturam de forma altamente organizada, em tecidos e órgãos. Para manter o equilíbrio e a vitalidade do organismo, elas precisam "conversar" entre si. Isso acontece por meio de mensageiros químicos denominados hormônios. Eles podem ser produzidos por glândulas especializadas ou um órgão próprio.

Pois bem, se vamos do átomo ao anjo, isso significa dizer que somos responsáveis pelos pensamentos e ações em nossas labutas diárias, pois temos zilhões de filhos a zelar e de dar um melhor exemplo de como proceder no processo evolutivo.

Como um educador, nossas atitudes ficaram gravadas nestes átomos que levaram consigo uma pequena carga nossa oriunda de ponderações pretéritas. Com isso, a questão da reforma íntima atinge não somente a nós, mas a todo um batalhão de futuros espíritos que se formarão ao chegarem ao nível consciencial.

Fazendo analogia com a própria estrutura do organismo, estamos em constante e mútua interdependência de tudo e todos. O corpo que abriga o espírito consciencial, tem, por isso, o dever de melhor se portar frente àqueles que

posteriormente irão também abrigar uma colônia de princípios inteligentes, edificando os fundamentos espirituais da nova humanidade, fazendo com que, a trajetória do espírito, após a saída do átomo logre o seu desiderato final.

Daí, passamos para a sobrevivência, não mais no Inferno, mas para a glória 
da alma imortal. Após a morte, ou seja, quando a vestimenta carnal perde sua finalidade de manifestação do espírito e fica esgotado das forças anímicas que o mantém, ele entra em processo de desagregação molecular, também conhecida como entropia, pois aquilo que mantinha as células unidas, o espírito, deixou de vivificar o corpo. Com isso, o corpo retorna ao "pó", levando com ele os desajustes que o acometeram. Mas para aonde vai o espírito?

Ao deixar o corpo físico, o Espírito não fica em estado letárgico, adormecido indefinidamente à espera do momento do Juízo Final. Sua posição na chamada Erraticidade pelo espiritismo, ou seja, as diversas camadas vibracionais existentes no mundo espiritual dar-se-á mediante a substância exarada dos pensamentos de cada mundo íntimo, fazendo com que sejamos atraídos, do mesmo modo que um ímã, para as regiões das quais tenhamos maior afinidade. Os caminhos astrais trilhados pelos andarilhos espirituais são resultados do arcabouço mentalemocional em que se encontra o recém-desencarnado.

Conforme se entende, todos os dias representam dias de julgamento e o fato de se ter despojado do corpo físico, não nos faz, de uma hora para outra, virarmos santos ou sermos capazes de saber todos os segredos do Céu e da Terra.

Continuamos a existir com as mesmas mazelas psíquicas e dúvidas que alimentávamos neste plano. A pedra fundamental da filosofia desta doutrina se refere à questão da responsabilidade pessoal, pois para cada ação, sofremos uma reação igual e em sentido contrário. É conhecida como lei de causa e efeito. Com este entendimento, a proposta de reencarnação se encaixa dentro do princípio de responsabilidade pessoal, estabelecendo um esquema de igual oportunidade evolutiva para todos que poderíamos denominar de "democracia espiritual".

A posição evolutiva da qual nos encontramos é resultado da força de nossos pensamentos que modelam nossos atos. Nossos erros de hoje resultarão nas dores de amanhã, pois o mundo que habitamos nos serve de escola onde o Espírito aprende suas lições mediante o palmilhar do longuíssimo caminho que nos leva à perfeição, possível através do acúmulo das experiências e sabedoria proporcionadas por um rosário imenso de vidas, que começam desde o alvorecer dos primeiros clarões da consciência indo até os mais elevados graus de conhecimento e moral. 
As duas forças, morte-renascimento e morte-sobrevivência, são, faces de uma mesma moeda, cada qual sendo parte integrante da outra. A morterenascimento mostra a necessidade do ciclo morte-vida-morte no intuito de aprimoramento do Espírito imortal, secundado pelo perispírito, seu duplo, vestimenta deste mesmo espírito que o acompanha na escalada evolutiva. Portanto, ambas as concepções estão corretas e são complementares. 


\section{REFERENCIAS}

ARIÈS, Philippe. O Homem diante da Morte. São Paulo: Editora Unesp, 2014.

KARDEC, Allan. O Livro dos Espíritos. São Paulo: Lake, 2013.

MIRANDA, Hermínio C.. Reencarnação e Imortalidade. Brasília: FEB, 2013.

MORIN, Edgar. O Homem e a Morte. Lisboa: Publicações Europa-América, 1970.

XAVIER, Francisco Cândido. No Mundo Maior. Rio de Janeiro: FEB, 1994. 